\title{
Hemodynamic properties and arterial structure in male rat offspring with fetal hypothyroidism
}

\author{
Mahboubeh Ghanbari ${ }^{1,2}$, Fatemeh Bagheripuor ${ }^{1,2}$, Abbas Piryaei ${ }^{3}$, Saleh Zahediasl ${ }^{1,2}$, Mahsa \\ Noroozzadeh $^{4}$ and Asghar Ghasemi ${ }^{1,2}$ \\ ${ }^{1}$ Endocrine Physiology Research Center, Research Institute for Endocrine Sciences, Shahid Beheshti University of Medical \\ Sciences, Tehran, Iran \\ ${ }^{2}$ Endocrine Research Center, Research Institute for Endocrine Sciences, Shahid Beheshti University of Medical Sciences, \\ Tehran, Iran \\ ${ }^{3}$ Department of Biology and Anatomical Sciences, School of Medicine, Shahid Beheshti University of Medical Sciences, \\ Tehran, Iran \\ ${ }^{4}$ Reproductive Endocrinology Research Center, Research Institute for Endocrine Sciences, Shahid Beheshti University of \\ Medical Sciences, Tehran, Iran
}

\begin{abstract}
Thyroid hormones (THs) play a crucial role in the development of different systems during fetal life; fetal hypothyroidism (FH) is associated with reduced cardiac function and dimensions in neonates. The aim of this study is to determine whether TH deficiency during fetal life is associated with arterial structural and hemodynamic changes during adulthood. Hypothyroidism was induced by adding 0.025\% 6-propyl-2-thiouracil in drinking water throughout pregnancy, while controls consumed only tap water. Hemodynamic parameters, cross-sectional area, intima-media thickness (IMT), and density of nuclei of smooth muscle cells and endothelial cells (ECs) in the aorta and mesenteric arteries were measured. Compared to controls, in the FH group, baseline systolic blood pressure $(105.7 \pm 3.1 \mathrm{vs}$. $87.9 \pm 3.3 \mathrm{~mm} \mathrm{Hg}, p<0.01)$, diastolic blood pressure $(64.4 \pm 1.7 v s .53 .2 \pm 2.1 \mathrm{~mm} \mathrm{Hg}, p<0.05)$, and mean arterial pressure $(80.9 \pm 2.1$ vs. $67.1 \pm 2.1 \mathrm{~mm} \mathrm{Hg}, p<0.01)$ were significantly lower. In addition, in the FH group, intensity and latency of response to phenylephrine were significantly lower and longer, respectively, as were the IMT and density of ECs in the aorta and superior mesenteric arteries. In conclusion, this study showed that TH deficiency during fetal life can have long-lasting functional and histological effects, which can compromise cardiovascular function during adulthood.
\end{abstract}

Key words: Fetal hypothyroidism - Blood pressure - Phenylephrine - Arterial structure - Rat

\begin{abstract}
Abbreviations: BP, blood pressure; DBP, diastolic blood pressure; ECs, endothelial cells; FH, fetal hypothyroidism; HR, heart rate; IMT, intima-media thickness; MAP, mean arterial pressure; PE, phenylephrine; PTU, 6-propyl-2-thiouracil; SBP, systolic blood pressure; SMCs, smooth muscle cells; THs, thyroid hormones; $\mathrm{TT}_{3}$, total triiodothyronine; $\mathrm{TT}_{4}$, total thyroxine.
\end{abstract}

\section{Introduction}

It is well known that thyroid hormones (THs) directly affect the peripheral vascular system and heart (Gomberg-Maitland and Frishman 1998). In adulthood, hypothyroidism is

Correspondence to: Asghar Ghasemi, Parvaneh Street No. 24, Velenjak, 1985717413 Tehran, Iran

E-mail: Ghasemi@endocrine.ac.ir associated with decrease of cardiac output and contractility, as well as normal or decreased resting heart rate (HR), whereas the systemic vascular resistance is increased (Rhee and Pearce 2011).

Fetal life and intrauterine growth conditions are strongly related to the physiological function and risk of disease during adulthood (Langley-Evans 2006). Development of the fetus is primarily dependent on its genetic equipment (York et al. 2014), as well as on the nutritional, hormonal, 
and metabolic influence during intrauterine growth (Tzanetakou et al. 2011).

Maternal hypothyroidism is a common clinical condition, affecting 2-5\% of pregnant women (Teng et al. 2013). The fetal thyroid gland is inactive until birth (Galton et al. 1999) and maternal THs are the only source of THs during fetal life (Santos et al. 2012). Adverse effects of TH deficiency during fetal development have been evaluated on various systems (Chattergoon et al. 2012; Karbalaei et al. 2013).

Few studies documented developmental effects of $\mathrm{TH}$ deficiency during fetal life on cardiovascular system function in adulthood, some show that TH deficiency during this period leads to lower HR with a reduced cardiac output and cardiac dimensions in infancy (Fouron et al. 1982). Animal studies have also shown that $\mathrm{TH}$ deficiency during fetal life up to 30 days after birth postpones the maturation of ventricular contractile proteins in rats (Chizzonite and Zak 1984); moreover, our previous study showed that HR, left ventricular developed pressure (LVDP) and the peak rates of positive and negative changes in left ventricular pressure $( \pm \mathrm{dp} / \mathrm{dt})$ are lower in isolated rat hearts from adult fetal hypothyroid (FH) rats (Ghanbari et al. 2015). Apparently insufficiency of THs during fetal life leads to a diminution of cardiac function in infancy. Since no data are available concerning the long-lasting effects of TH deficiency during fetal period on hemodynamic parameters and arterial structure in adulthood, the purpose of this study was to evaluate the effects of deficiency of THs during pregnancy on hemodynamic parameters, and their responses to phenylephrine $(\mathrm{PE})$, as well as aorta/mesenteric arteries wall histological structures in adult rat offspring.

\section{Materials and Methods}

\section{Animals}

All animals were obtained from the Research Institute for Endocrine Sciences (RIES) of Shahid Beheshti University of Medical Sciences, Tehran, Iran. Animals were housed in polypropylene cages $(42 \mathrm{~cm} \times 28 \mathrm{~cm} \times 15 \mathrm{~cm})$ in a $12-\mathrm{h}$ light/dark cycle at $22 \pm 2{ }^{\circ} \mathrm{C}$ with food and water ad libitum. Experimental procedures were conducted in accordance with the local ethics committee rules for the care and use of laboratory animals of the RIES.

\section{Hypothyroidism induction}

Virgin female Wistar rats $(200 \pm 10 \mathrm{~g}, n=33)$ at the ovulatory phase (determined by vaginal smears) were housed overnight with male rats $(300 \pm 20 \mathrm{~g}, n=33)$ for mating (one female and one male rat in each cage). Following pregnancy, female rats were randomly divided into the hy- pothyroid and control groups. To induce hypothyroidism, 0.025\% (250 ppm) 6-propyl-2-thiouracil (PTU) (SigmaAldrich, Hamburg, Germany) was added to the drinking water of hypothyroid rats from the first day of pregnancy until delivery day (Farahani et al. 2013), while the control group consumed only tap water. After birth, the weight of the neonates in both groups ( $n=45-31 /$ groups) was measured weekly (A \& D scale, EK-300i, Japan; sensitivity $0.01 \mathrm{~g}$ ) from the first day of birth till the end of the third month.

\section{$T T_{3}$ and $T T_{4}$ measurements}

To assess TH status, blood samples were obtained from both mothers (after delivery) and offspring (at birth and days 7 , $14,21,28$, and 90$)$, centrifuged $\left(3000 \times g, 10 \mathrm{~min}\right.$ at $\left.4^{\circ} \mathrm{C}\right)$, and the sera were stored at $-80^{\circ} \mathrm{C}$ until the time of assay. Total triiodothyronine $\left(\mathrm{TT}_{3}\right)$ and total thyroxine $\left(\mathrm{TT}_{4}\right)$ levels were measured by ELISA kits (PishtaztebZaman Co., Iran). Intraand interassay coefficients of variations were $3.7 \%$ and $4.3 \%$ for $\mathrm{TT}_{3}$ and $5.3 \%$ and $5.9 \%$ for $\mathrm{TT}_{4}$, respectively.

\section{Surgical procedures}

Adult male offspring in the $\mathrm{FH}$ and control groups ( $n=10$ each group) were assessed at age $95 \pm 2$ days after birth. Rats were anesthetized with sodium pentobarbital $(60 \mathrm{mg} / \mathrm{kg}$, i.p.) (Sigma, Hamburg, Germany) which comparing to other anesthetics minimally affects the hemodynamic parameters (Bencze et al. 2013). The animals were heated to prevent the effect of temperature decline on cardiovascular parameters. Body temperature was monitored to maintain a constant rectal temperature. A flexible polyethylene cannula (PE50) containing heparin solution $(40 \mathrm{U} / \mathrm{ml})$ (Ferreira et al. 2009) was inserted in the left femoral artery and connected to a pressure transducer (MLT844-Sweden). Hemodynamic parameters including systolic blood pressure (SBP), diastolic blood pressure (DBP), mean arterial pressure (MAP), and HR were then recorded with a power lab system (AD Instruments, ML866, Australia). The left femoral vein was also cannulated to provide venous access.

\section{Measurement of cardiovascular system response to $P E$}

Baseline levels of hemodynamic parameters were recorded for a period of 20 minutes to allow their stabilization, after which SBP, DBP, MAP, and HR were measured. After documenting their baseline values, the PE (Sigma-USA) was injected in both groups intravenously in doses of 0.25 , $0.5,1,2,5,8$, and $10 \mu \mathrm{g} / \mathrm{kg}$, respectively (Nijsen et al. 2001; Loss Ide et al. 2007; Cannesson et al. 2012; Guimaraes et al. 2012) and the HR and blood pressure (BP) were recorded. Peak of hemodynamic changes was recorded for assessment 
of response to PE. After the injection of each dose, and before the injection of next dose, the BP and HR levels were allowed to return to their baseline levels.

\section{Measurement of heart weight}

In both $\mathrm{FH}$ and control groups at the age of 7, 14, 21, 28 and $\sim 95$ days, the hearts of part of animals (5-6 animals at each age) were removed, their weights were measured by a digital scale (Sartorius, TE124S, d = $0.1 \mathrm{mg}$, Gottingen, Germany) and the heart to body weight ratio was calculated.

\section{Histological study}

To study the histology of the thoracic aorta and small mesenteric arteries, adult offspring at age $\sim 95$ days in both $\mathrm{FH}$ and control groups ( $n=10$ in each group) were deeply anesthetized with sodium pentobarbital as described previously and perfused with $0.9 \% \mathrm{NaCl}$; specimens of the thoracic aorta ( $1 \mathrm{~cm}$ of the middle part) as well as superior mesenteric and small intestinal arteries were removed and fixed in $10 \%$ neutral formalin. Specimens were processed in paraffin and $6 \mu \mathrm{m}$ (for aorta) and $5 \mu \mathrm{m}$ (for mesenteric arteries) thick slices were then stained with hematoxylin and eosin. Four sections at equal intervals ( 1 slice every $30 \mu \mathrm{m}$ ) were selected in each sample (Morvan et al. 2013) and digitally photographed using a Nikon microscope (ECLIPSE-E200. Tokyo, Japan) at magnifications of $40 \times, 400 \times$, and $1000 \times$. Image software (1.44p.NIH.USA) was then used to calculate cross-sectional areas (CSA) in all slices.

A rectangular area with a size of $2200 \mu \mathrm{m}^{2}$ (for aorta), $1000 \mu \mathrm{m}^{2}$ (for superior mesenteric arteries) and $600 \mu \mathrm{m}^{2}$ (for intestinal mesenteric arteries), was selected in four fields in sections at angles $0^{\circ}, 90^{\circ}, 180^{\circ}, 270^{\circ}$ and then the intima-media thickness (IMT) and density of nuclei of smooth muscle cells (SMCs), expressed as a number of SMCs in this area, were measured in aorta and mesenteric arteries (Olivetti et al. 1982); an intimal segment with length of $80 \mu \mathrm{m}$ (for aorta) and $180 \mu \mathrm{m}$ (for superior mesenteric arteries) was selected in the angles and density of nuclei of endothelial cells (ECs), defined as number of nuclei of the thin layer of cells that lines the selected part interior surface of vessels, was counted. In the intestinal mesenteric arteries, the numbers of nuclei of ECs in round cross-sections with equal diameter were counted. The average of the four regions was calculated for each section (Adijiang et al. 2008).

\section{Statistical analysis}

Values were expressed as mean \pm SEM. Data were analyzed by GraphPad Prism software (Version 5). Two-way ANOVA followed by Bonferroni test was used for comparing changes in offspring body weight and hemodynamic parameters between groups. Student's $t$-test was used to compare histological parameters, heart weight and THs between groups; $p$ values $<0.05$ were considered statistically significant.

\section{Results}

\section{Hormone measurements}

Treatment with PTU was effective in inducing hypothyroidism; serum $\mathrm{TT}_{4}$ levels in mothers (at delivery day) and neonates (at birth and after 7, and 14 days), was significantly lower in FH group compared to controls; however, no significant difference was observed in offspring at ages of 21,28, and 90 days; $\mathrm{TT}_{3}$ was also lower in mothers (at delivery day) and neonates (until 21 days) in the FH group, and the offspring became euthyroid at the age of 28 and 90 days (Table 1 ).

\section{Effect of FH on heart, body weight and baseline hemodynamic parameters}

Body weight in the FH group was significantly lower than in controls from birth until week 12 , there was no difference at

Table 1. Serum levels of thyroid hormones and heart weight in control and hypothyroid rats

\begin{tabular}{|c|c|c|c|c|c|c|c|c|}
\hline \multirow[b]{2}{*}{ Groups } & \multicolumn{2}{|c|}{$\begin{array}{l}\text { Total thyroxine } \\
\qquad(\mu \mathrm{g} / \mathrm{dl})\end{array}$} & \multicolumn{2}{|c|}{$\begin{array}{l}\text { Total triiodothyronine } \\
\text { (ng / dl) }\end{array}$} & \multicolumn{2}{|c|}{$\begin{array}{l}\text { Heart weight } \\
(\mathrm{g})\end{array}$} & \multicolumn{2}{|c|}{ Heart weight/Body weight } \\
\hline & Control & Hypothyroid & Control & Hypothyroid & Control & Hypothyroid & Control & Hypothyroid \\
\hline Mothers $(n=10)$ & $2.4 \pm 0.2$ & $0.5 \pm 0.1^{\text {\# }}$ & $93.4 \pm 3.8$ & $51.7 \pm 4.9^{\ddagger}$ & - & - & - & - \\
\hline $\operatorname{Birth}(n=10)$ & $0.7 \pm 0.1$ & $0.4 \pm 0.1^{\ddagger}$ & $62.9 \pm 3.4$ & $39.5 \pm 4.3^{\ddagger}$ & - & - & - & - \\
\hline 7 days rats $(n=6)$ & $5.2 \pm 0.4$ & $0.6 \pm 0.2^{\ddagger}$ & $65.1 \pm 4.4$ & $27.6 \pm 7.1^{\dagger}$ & $0.08 \pm 0.004$ & $0.05 \pm 0.002^{\dagger}$ & $0.006 \pm 0.0004$ & $0.004 \pm 0.0002^{*}$ \\
\hline 14 days rats $(n=6)$ & $6.9 \pm 0.7$ & $2.1 \pm 0.1^{\ddagger}$ & $86.4 \pm 10.3$ & $46.02 \pm 9.2^{\dagger}$ & $0.14 \pm 0.01$ & $0.11 \pm 0.01^{*}$ & $0.005 \pm 0.0003$ & $0.01 \pm 0.0005^{\dagger}$ \\
\hline 21 days rats $(n=6)$ & $5.8 \pm 0.3$ & $5.4 \pm 0.3$ & $98.1 \pm 3.6$ & $65.3 \pm 7.8^{\dagger}$ & $0.15 \pm 0.002$ & $0.13 \pm 0.01^{*}$ & $0.004 \pm 0.0001$ & $0.006 \pm 0.0004^{\dagger}$ \\
\hline 28 days rats $(n=5)$ & $5.7 \pm 0.2$ & $4.4 \pm 0.7$ & $108.9 \pm 12.5$ & $97.9 \pm 10.5$ & $0.26 \pm 0.01$ & $0.16 \pm 0.003^{\ddagger}$ & $0.004 \pm 0.0003$ & $0.004 \pm 0.0001$ \\
\hline 95 days rats $(n=10)$ & $3.8 \pm 0.1$ & $3.4 \pm 0.2$ & $95.7 \pm 4.3$ & $87.7 \pm 5.3$ & $1.1 \pm 0.1$ & $0.9 \pm 0.02^{*}$ & $0.004 \pm 0.0002$ & $0.003 \pm 0.00006$ \\
\hline
\end{tabular}

Each value is the mean $\pm \mathrm{SEM} ;{ }^{*} p<0.05,{ }^{\dagger} p<0.01,{ }^{*} p<0.001 v s$. control. 


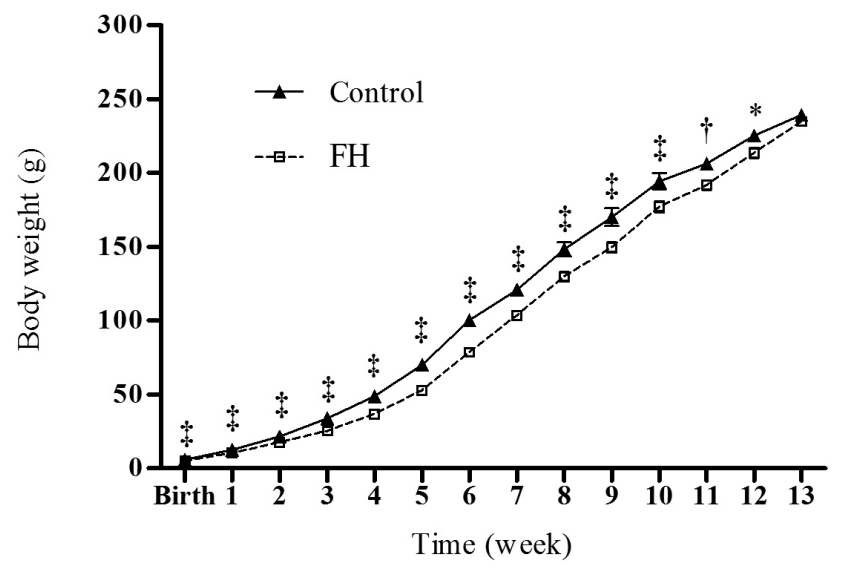

Figure 1. Comparison of body weight of offspring with fetal hypothyroidism $(\mathrm{FH})$ and control groups. Values are means \pm SEM ( $n=45-31$ /groups); repeated measure ANOVA followed by Bonferroni test was used for comparing changes; ${ }^{*} p<0.05,{ }^{\dagger} p<$ $0.01,{ }^{\ddagger} p<0.001$ vs. control.

week 13 (Fig. 1). Compared to control offspring, heart weight in the FH group was significantly lower at days 7, 14, 21, 28 and $\sim 95$. The heart to body weight ratio was significantly lower at days 7, increased at days 14 and 21, and did not differ significantly at days 28 and $\sim 95$ (Table 1 ). In adult offspring (day 95), basal levels of the MAP, SBP, and DBP

Table 2. Baseline values of hemodynamic parameters in control and fetal hypothyroidism rat offspring

\begin{tabular}{lcc}
\hline & \multicolumn{2}{c}{ Adult rats $(95 \pm 2$ days $)$} \\
\cline { 2 - 3 } & Control & FH \\
\hline HR $(\mathrm{bpm})$ & $393.4 \pm 10.6$ & $364 \pm 15.1$ \\
SBP $(\mathrm{mm} \mathrm{Hg})$ & $105.7 \pm 3.1$ & $87.9 \pm 3.8^{\dagger}$ \\
DBP (mm Hg) & $64.4 \pm 1.7$ & $53.2 \pm 2.2^{*}$ \\
MAP (mm Hg) & $80.9 \pm 2.1$ & $67.1 \pm 2.1^{\dagger}$ \\
\hline
\end{tabular}

FH, fetal hypothyroidism; HR, heart rate; SBP, systolic blood pressure; DBP, diastolic blood pressure; MAP, mean arterial pressure. Each value is the mean $\pm \operatorname{SEM}(n=10) ;{ }^{\star} p<0.05,{ }^{\dagger} p<0.01 v s$. control. in $\mathrm{FH}$ rats were lower than controls, whereas HR was not different (Table 2).

Response of the cardiovascular system to $P E$

In response to various doses of $\operatorname{PE}(0.25,0.5,1,2,5,8$ and $10 \mathrm{mg} / \mathrm{kg} /$ intravenous) increases in MAP, SBP, and DBP were significantly lower in adult offspring of hypothyroid mothers, compared to controls, the decrease in HR was, however, significantly higher than controls (Fig. 2). Latency of response to PE injection (the first dose) was significantly longer in the FH group $(16.29 \pm 1.0 \mathrm{~s})$ than in controls $(12.7 \pm 0.9 \mathrm{~s})$.

\section{Histology of the arterial walls}

The density of SMC nuclei and CSA for thoracic aorta, superior mesenteric, and small intestinal arteries did not differ significantly between the FH and control groups ( $\mathrm{Ta}-$ ble 3). IMT and average ECs density in walls of the thoracic aorta (Fig. 3) and superior mesenteric artery but not small intestinal artery were, however, lower in FH rats (Fig. 3 and Fig. 4).

\section{Discussion}

This study showed that maternal hypothyroidism during pregnancy causes reduction of baseline hemodynamic parameters (SBP, DBP, and MAP) and decreases the intensity but raises latency of their response to $\mathrm{PE}$ in adult offspring; moreover it is accompanied by vascular structural changes. These findings highlight the fact that maternal hypothyroidism can disturb cardiovascular function during adulthood.

PTU administration induced hypothyroidism in mother rats during pregnancy, which affected $\mathrm{TH}$ status of their offspring. The offspring from hypothyroid mothers had significantly lower $\mathrm{TT}_{4}$ and $\mathrm{TT}_{3}$ levels, until the age of 21 and 28 days, respectively. These findings are in line with data indicating that maturation of $\mathrm{TH}$ activity continues up to 4 weeks of postnatal life in rats (Forhead and Fowden 2014).

Table 3. Quantitative evaluation of thoracic aorta and mesenteric arteries wall

\begin{tabular}{|c|c|c|c|c|c|c|}
\hline & \multicolumn{2}{|c|}{ Thoracic aorta } & \multicolumn{2}{|c|}{ Superior mesenteric artery } & \multicolumn{2}{|c|}{ Intestinal mesenteric artery } \\
\hline & Control & FH & Control & $\mathrm{FH}$ & Control & $\mathrm{FH}$ \\
\hline $\operatorname{CSA}\left(\mu \mathrm{m}^{2}\right)$ & $1154904 \pm 70851.5$ & $1106914 \pm 67160.2$ & $109527.6 \pm 42641.1$ & $118580.1 \pm 50583.8$ & $6853.7 \pm 445.3$ & $5550.1 \pm 496.1$ \\
\hline $\operatorname{IMT}(\mu \mathrm{m})$ & $90.8 \pm 1.2$ & $73.4 \pm 2.3^{\ddagger}$ & $40.6 \pm 1.2$ & $29.8 \pm 0.5^{\ddagger}$ & $23.4 \pm 1.3$ & $22.02 \pm 1.04$ \\
\hline NSMC & $7.1 \pm 0.2$ & $7.2 \pm 0.3$ & $4.1 \pm 0.1$ & $4.2 \pm 0.1$ & $3.04 \pm 0.13$ & $3.4 \pm 0.1$ \\
\hline NEC & $4.8 \pm 0.1$ & $3.2 \pm 0.2^{\ddagger}$ & $11.2 \pm 0.1$ & $8.1 \pm 0.4^{\ddagger}$ & $34.6 \pm 1.1$ & $37.9 \pm 1.2$ \\
\hline
\end{tabular}

FH, fetal hypothyroidism; CSA, cross sectional area; IMT, intima-media thickness; NSMC, nuclei of smooth muscle cells; NEC, nuclei of endothelial cell. Each value is the mean $\pm \operatorname{SEM}(n=10) ;{ }^{\ddagger} p<0.001 v s$. control. 

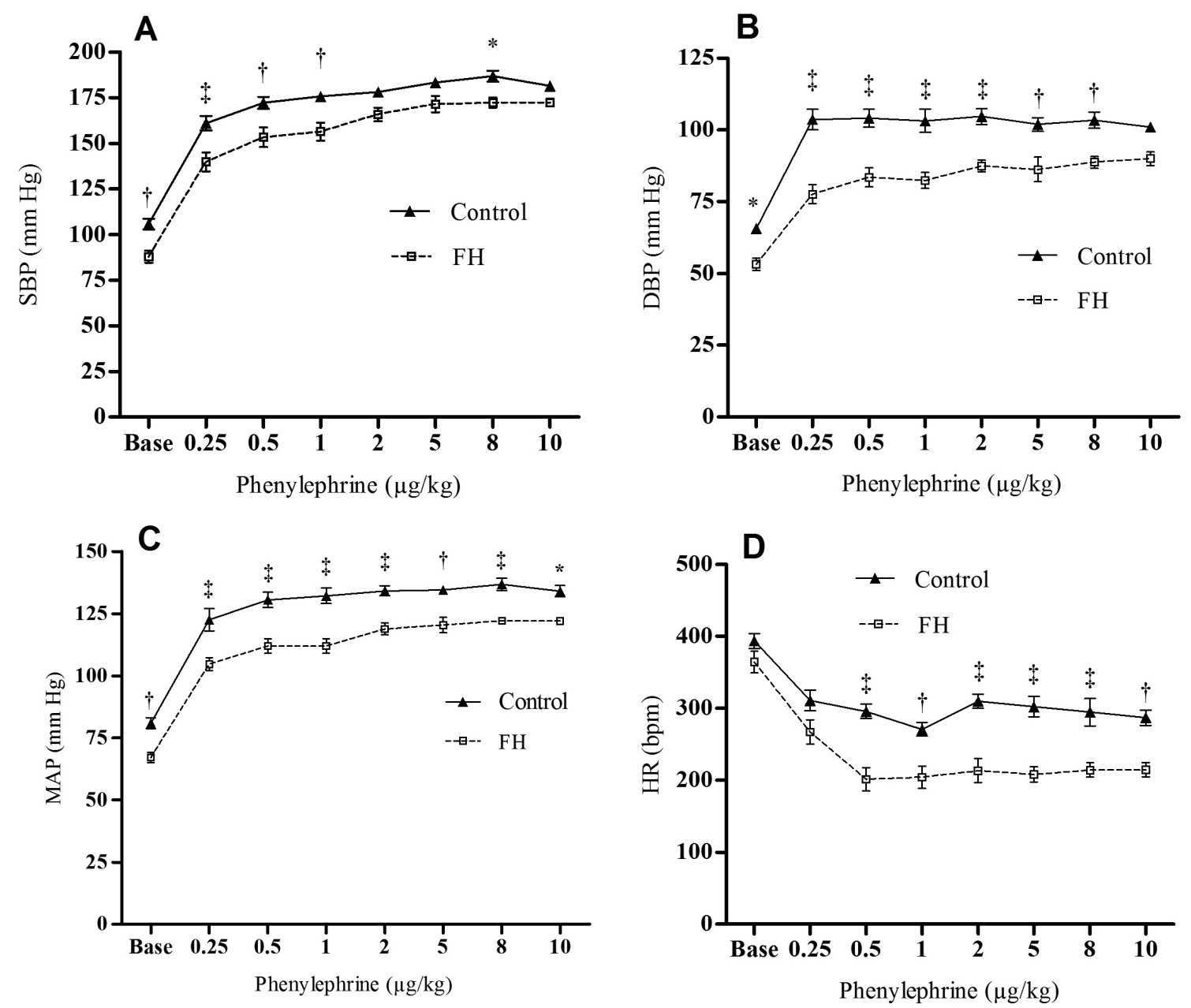

Figure 2. The effect of fetal hypothyroidism (FH) on response of the hemodynamic parameters to phenylephrine. Response of the hemodynamic parameters including, systolic blood pressure (SBP; A), diastolic arterial pressure (DBP; B), mean arterial pressure (MAP; C), and heart rate (HR; D) to phenylephrine were compared between offspring with FH and control groups. All values are means \pm SEM; $n=10$; repeated measure ANOVA followed by Bonferroni test was used for comparing between groups; all ${ }^{*} p<0.05,{ }^{\dagger} p<0.01,{ }^{\ddagger} p<$ 0.001 vs. control.

Decreased activity of $5^{\prime}$-monodeiodinase in offspring with $\mathrm{FH}$ may partly explain the different times of $\mathrm{TT}_{3}$ and $\mathrm{TT}_{4}$ restoration to normal levels (Ahmed et al. 2010). Compared with adult offspring, neonates from control mothers had significantly higher $\mathrm{TT}_{4}$ findings similar to those of a previous report (David Kieffer et al. 1976). Although the reason for this difference remains unknown, sudden increase in TSH secretion and stimulation of $\mathrm{TT}_{4}$ secretion have, however, been reported in humans at birth (Williams et al. 2004).

In this study, TH deficiency during fetal life reduced body weight from birth until week 12; in addition, heart weight was lower in offspring of hypothyroid mothers. FH reduces the secretion of growth hormone and IGF-I leading possibly to reduced muscle mass (Fowden 1995), which may in turn cause body weight and heart weight loss.
Baseline levels of SBP, DBP, and MAP in adult offspring of the $\mathrm{FH}$ group were lower $(16.8 \%, 17.4 \%, 17.1 \%$, respectively) than in controls. These results are similar to those of Chen et al. (2005) showing thyroidectomy in sheep embryo caused a reduction of MAP. In addition, mutation in the $\mathrm{TH}$ receptor alpha $1\left(\mathrm{TRa}_{1}\right)$ decreased $\mathrm{BP}$ in other study (Bochukova et al. 2012). Blood pressure is determined by cardiac output and peripheral resistance, heart size and contractility could affect cardiac output (Brzezinski 1990). In our study, heart weight was lower in the FH group until adulthood; moreover we recently showed that also LVDP and $\pm \mathrm{dp} / \mathrm{dt}_{\max }$ (indices of contractility) were lower in the isolated heart of offspring with FH (Ghanbari et al. 2015), so the lower BP in FH group could hence be due to reduced cardiac output. 


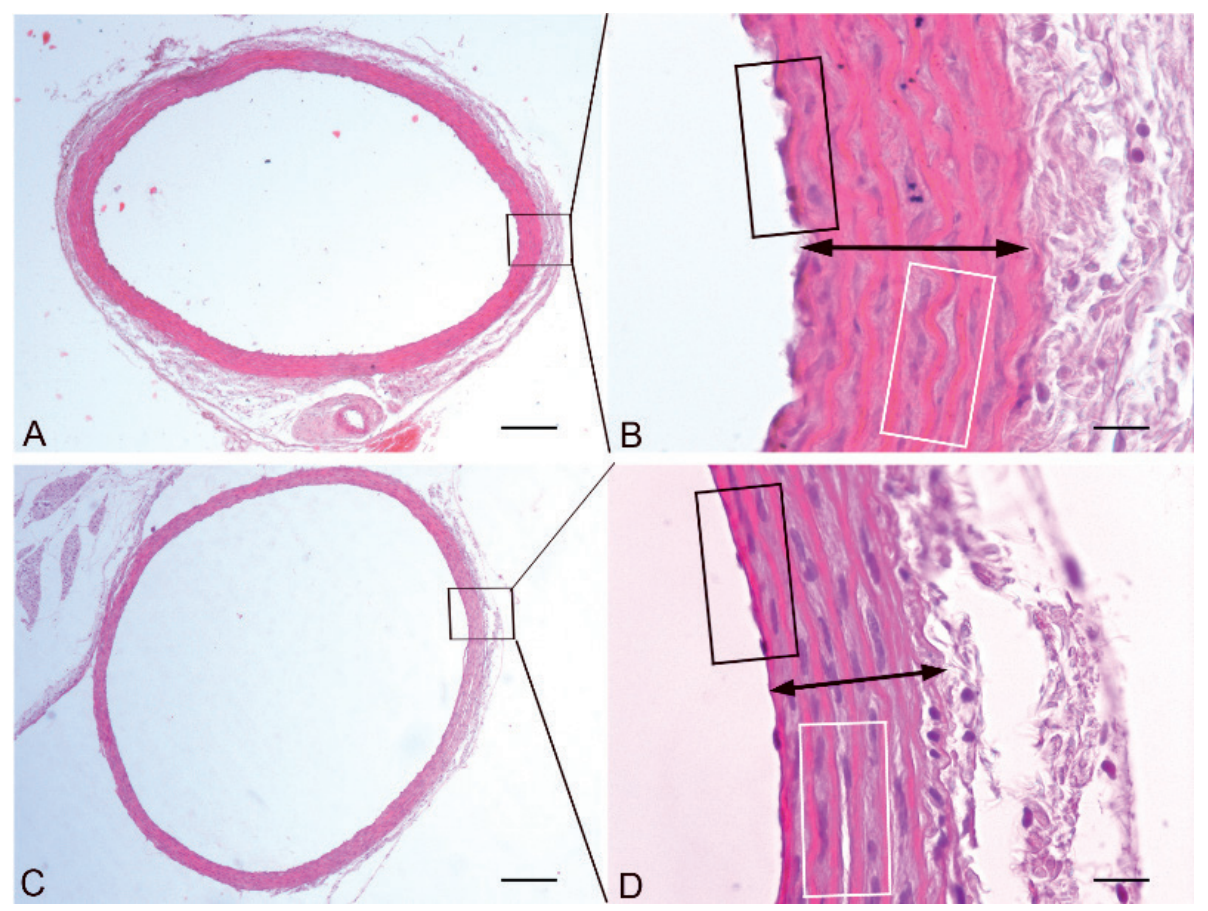

Figure 3. Histological changes in the thoracic aorta wall of rats with fetal hypothyroidism. Panels A and B show aorta section from control rats; the measured intima-media thickness (IMT) is illustrated with a black arrow. Nuclei of endothelial cell (ECs) were counted in cross sections in a length of $80 \mu \mathrm{m}$ (indicated by a black rectangle), and nuclei of smooth muscle cells (SMCs) were counted in cross sections in an area $2200 \mu \mathrm{m}^{2}$ (indicated by a white rectangle). Panels $\mathrm{C}$ and $\mathrm{D}$ show the IMT, SMCs and ECs in the fetal hypothyroidism group $(n=10)$. Scale bars: $200 \mu \mathrm{m}$ in panels A and C; $20 \mu \mathrm{m}$ in panels B and D. Student's $t$-test was used to compare the two groups.
Contrary to the above mentioned results, Santos et al. (2012) report that FH induces hypertension. Although the reason for this discrepancy is not exactly clear, explanations include difference in types of antithyroid drugs used (PTU $v s$. methimazole), time of drug administration during pregnancy (first day of conception until delivery $v s$. day 9 until delivery), and age of rats at time of BP measurement $(\sim 95$ days vs. 60 days). Maternal hypothyroid status during initial or late gestation could affect outcome (Idris et al. 2005). Santos et al. in their study also combined the results obtained in male and female rats. The sex-associated differences in blood pressure, observed in humans, have also been documented
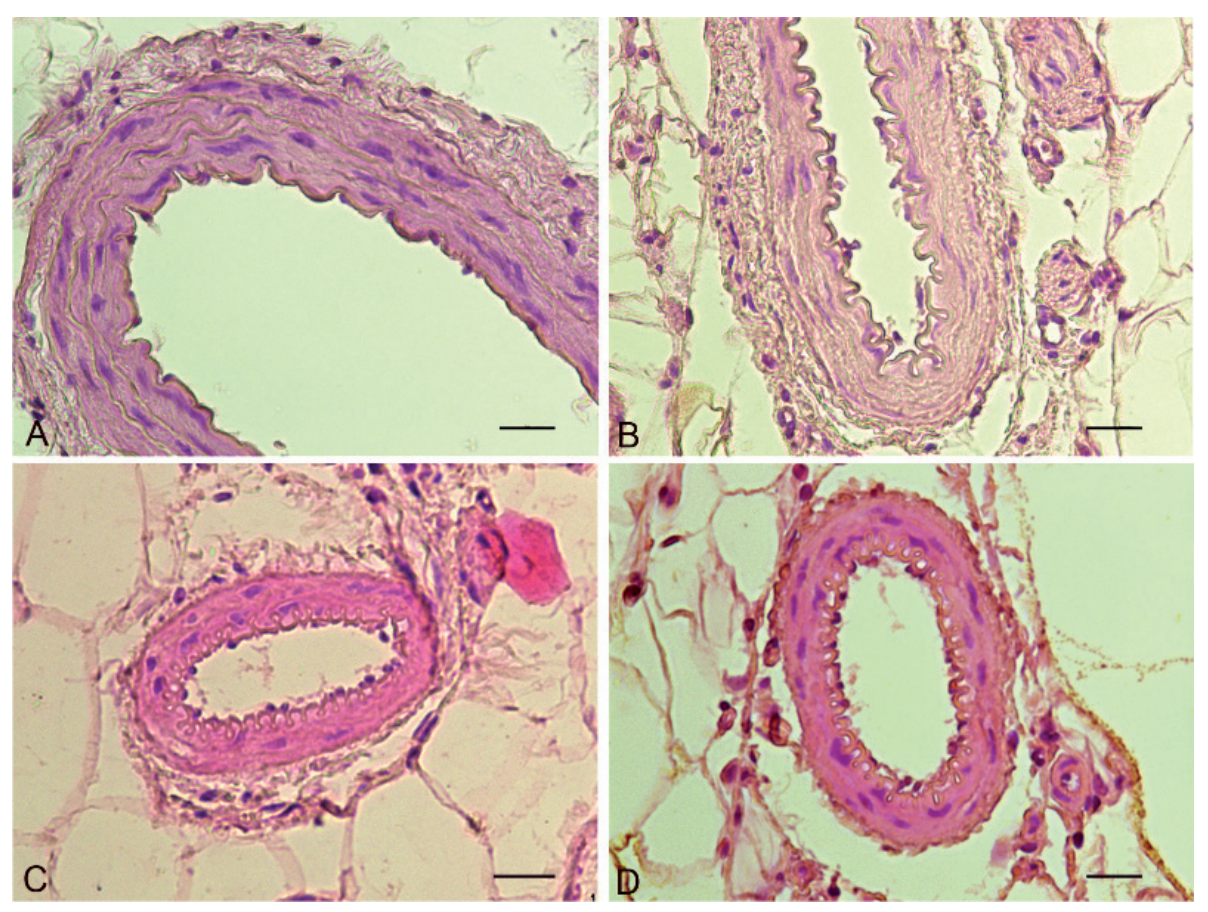

Figure 4. Histological changes in the mesenteric arteries wall of rats with fetal hypothyroidism. Panels A and B show superior mesenteric arteries section of both control and fetal hypothyroidism (FH) group, respectively; the intima-media thickness, smooth muscle cells and number of endothelial cell in FH offspring compared to the two groups. Panels $\mathrm{C}$ and $\mathrm{D}$ show these parameters in the intestinal arteries section in control and $\mathrm{FH}$ group, respectively $(n=10)$. Scale bars: $20 \mu \mathrm{m}$ in all panels. Student's $t$-test was used to compare the two groups. 
in animal models (Reckelhoff 2001). Finally, outcomes of impaired intrauterine growth may vary according to age of offspring ( Roland et al. 2010; Karbalaei et al. 2013), results that justify both ours and those of Santos et al. (2012).

Following injection of $\mathrm{PE}$, an $\alpha_{1}$-adrenergic agonist, SBP, DBP, and MAP were lower in the FH group than in controls. These findings demonstrate that $\mathrm{FH}$ decreases the vasoconstriction and inotropic effects of PE. It may be associated with decreased numbers of $\alpha_{1}$ and $\beta$ adrenergic receptors in the myocardium (Noguchi and Whitsett 1982), and decreased arterial response to PE due to impairment in L-type $\mathrm{Ca}^{2+}$ channel function (Sedaghat et al. 2015) found in hypothyroid offspring.

The IMT and density of ECs were lower in thoracic aorta and superior mesenteric arteries of adult offspring with $\mathrm{FH}$, compared to controls, findings supported by data demonstrating decrease in IMT of the aortic wall in adult hypothyroid rats (Tousson et al. 2012). Presence of iodothyronine deiodinase enzymes in SMCs of the aorta in rats (Toyoda et al. 2009) and the expression of TH receptors in coronary ECs of mice (Makino et al. 2009) and bovine aorta (Hu et al. 1994) suggests that during adulthood, arteries are a target for THs. They bind to integrin $\alpha v \beta 3$ in the plasma membrane of the ECs (Bergh et al. 2005) and activate the mitogen-activated protein kinases cascade, increasing angiogenesis (Davis et al. 2004) and proliferation of ECs via the fibroblast growth factor (Al Husseini et al. 2013).

Arterial structural changes observed in our study, can affect cardiovascular system function. Blood pressure is known to have a direct association with IMT (Ciobanu et al. 2013); in addition ECs by releasing both vasoconstrictor and vasodilator agents, could affect hemodynamic parameters (Vane et al. 1990).

This is the first study addressing the effects of FH on the histological structure of arterial walls. Nevertheless, this study has its limitations which should be considered in the interpretation of data; first, TSH levels were not measured in this study, however, previous reports from our laboratory (Ghasemi et al. 2013) indicate that in this model of $\mathrm{FH}$, serum TSH levels are comparable between control and FH groups during adulthood. Second, in this study, arterial wall structure was only assessed by IMT and SMC nuclei per area; both passive (elastic and collagenous connective tissue) and active (smooth muscle) component could, however, affect viscoelastic properties of the arterial wall and it has been reported that the passive component changes in hypothyroidism (Zaki and Youssef 2013). Third, we did not measure inflammatory markers, which are related to hypothyroidism and can lead to changes in the arterial wall (Dizdarevic-Bostandic et al. 2013).

One final word, PTU was used to induce hypothyroidism during pregnancy. Thioamide drugs such as PTU and methimazole have been categorized as class $\mathrm{D}$ drugs in pregnancy (Nambiar et al. 2014) and they are the treatment of choice for thyrotoxicosis in pregnancy (Diav-Citrin and Ornoy 2002), when other treatments including radiotherapy and thyroidectomy are contraindicated (Taylor and Vaidya 2012). PTU and methimazole have similar placental transfer kinetics (DiavCitrin et al. 2002). Due to the fetal teratogenicity associated with methimazole (Laurberg and Andersen 2014), PTU is considered the first-line in the treatment of Graves' disease during pregnancy (Chattaway and Klepser 2007). PTU could, however, induce hepatitis in fetus (Taylor and Vaidya 2012) and sometimes, changing from PTU therapy after first trimester to methimazole is considered to be the optimum treatment during pregnancy (Taylor and Vaidya 2012).

In conclusion, offspring born from hypothyroid mothers have lower values of hemodynamic parameters in adulthood; in addition, their response to $\alpha_{1}$-adrenergic agonist is lower than in controls. These changes may be associated with microstructural modifications including decreased IMT and ECs in arteries. THs could be a key factor in development of the cardiovascular system, and warrant more attention being paid to pregnant women with hypothyroidism.

Acknowledgements. This study was supported by a grant No. 542 from the Endocrine Physiology Research Center, Research Institute for Endocrine Sciences, Shahid Beheshti University of Medical Sciences. We would like to thank Ms N. Shiva, an academic faculty member, for critical editing of English grammar and syntax of the manuscript.

\section{References}

Adijiang A., Goto S., Uramoto S., Nishijima F., Niwa T. (2008): Indoxyl sulphate promotes aortic calcification with expression of osteoblast-specific proteins in hypertensive rats. Nephrol. Dial. Transplant. 23, 1892-1901 http://dx.doi.org/10.1093/ndt/gfm861

Ahmed O., Abd El-Tawab S. A., Ahmed R. (2010): Effects of experimentally induced maternal hypothyroidism and hyperthyroidism on the development of rat offspring: I. The development of the thyroid hormones-neurotransmitters and adenosinergic system interactions. Int. J. Dev. Neurosci. 28, 437-454 http://dx.doi.org/10.1016/j.ijdevneu.2010.06.007

Al Husseini A., Bagnato G., Farkas L., Gomez-Arroyo J., Farkas D., Mizuno S., Kraskauskas D., Abbate A., Van Tassel B., Voelkel N. F., Bogaard H. J. (2013): Thyroid hormone is highly permissive in angioproliferative pulmonary hypertension in rats. Eur. Respir. J. 41, 104-114 http://dx.doi.org/10.1183/09031936.00196511

Bencze M., Behuliak M., Zicha J. (2013): The impact of four different classes of anesthetics on the mechanisms of blood pressure regulation in normotensive and spontaneously hypertensive rats. Physiol. Res. 62, 471-478

Bergh J. J., Lin H. Y., Lansing L., Mohamed S. N., Davis F. B., Mousa S., Davis P. J. (2005): Integrin alphaVbeta3 contains a cell surface receptor site for thyroid hormone that is linked to activation of mitogen-activated protein kinase and induction of angiogenesis. Endocrinology 146, 2864-2871 
http://dx.doi.org/10.1210/en.2005-0102

Bochukova E., Schoenmakers N., Agostini M., Schoenmakers E., Rajanayagam O., Keogh J. M., Henning E., Reinemund J., Gevers E., Sarri M. (2012): A mutation in the thyroid hormone receptor alpha gene. N. Engl. J. Med. 366, 243-249 http://dx.doi.org/10.1056/NEJMoa1110296

Brzezinski W. A. (1990): Blood pressure. In: Clinical Methods: The History, Physical, and Laboratory Examinations. (Eds.: Walker H. K., Hall W. D., Hurst J. W.) 3rd ed., Boston

Cannesson M., Jian Z., Chen G., Vu T. Q., Hatib F. (2012): Effects of phenylephrine on cardiac output and venous return depend on the position of the heart on the Frank-Starling relationship. J. Appl. Physiol. 113, 281-289 http://dx.doi.org/10.1152/japplphysiol.00126.2012

Chattaway J. M., Klepser T. B. (2007): Propylthiouracil versus methimazole in treatment of Graves' disease during pregnancy. Ann. Pharmacother. 41, 1018-1022 http://dx.doi.org/10.1345/aph.1H535

Chattergoon N. N., Giraud G. D., Louey S., Stork P., Fowden A. L., Thornburg K. L. (2012): Thyroid hormone drives fetal cardiomyocyte maturation. FASEB J. 26, 397-408 http://dx.doi.org/10.1096/ff.10-179895

Chen K., Carey L. C., Valego N. K., Liu J., Rose J. C. (2005): Thyroid hormone modulates renin and ANG II receptor expression in fetal sheep. Am. J. Physiol. Regul. Integr. Comp. Physiol. 289, R1006-1014 http://dx.doi.org/10.1152/ajpregu.00046.2005

Chizzonite R. A., Zak R. (1984): Regulation of myosin isoenzyme composition in fetal and neonatal rat ventricle by endogenous thyroid hormones. J. Biol. Chem. 259, 12628-12632

Ciobanu A. O., Gherghinescu C. L., Dulgheru R., Magda S., Dragoi Galrinho R., Florescu M., Guberna S., Cinteza M., Vinereanu D. (2013): The impact of blood pressure variability on subclinical ventricular, renal and vascular dysfunction, in patients with hypertension and diabetes. Maedica (Buchar) 8, 129-136

David Kieffer J., Morver H., Federico P., Maloof F. (1976): Pituitarythyroid axis in neonatal and adult rats: comparison of the sexes. Endocrinology 98, 295-304 http://dx.doi.org/10.1210/endo-98-2-295

Davis F. B., Mousa S. A., O'connor L., Mohamed S., Lin H. Y., Cao H. J., Davis P. J. (2004): Proangiogenic action of thyroid hormone is fibroblast growth factor-dependent and is initiated at the cell surface. Circ. Res. 94, 1500-1506 http://dx.doi.org/10.1161/01.RES.0000130784.90237.4a

Diav-Citrin O., Ornoy A. (2002): Teratogen update: antithyroid drugs - methimazole, carbimazole, and propylthiouracil. Teratology 65, 38-44 http://dx.doi.org/10.1002/tera.1096

Dizdarevic-Bostandic A., Burekovic A., Velija-Asimi Z., Godinjak A. (2013): Inflammatory markers in patients with hypothyroidism and diabetes mellitus type 1. Med. Arh. 67, 160-161 http://dx.doi.org/10.5455/medarh.2013.67.160-161

Farahani H., Ghasemi A., Roghani M., Zahediasl S. (2013): Effect of neonatal hypothyroidism on carbohydrate metabolism, insulin secretion, and pancreatic islets morphology of adult male offspring in rats. J. Endocrinol. Invest. 36, 44-49

Ferreira A. J., Shenoy V., Yamazato Y., Sriramula S., Francis J., Yuan L., Castellano R. K., Ostrov D. A., Oh S. P., Katovich M. J.,
Raizada M. K. (2009): Evidence for angiotensin-converting enzyme 2 as a therapeutic target for the prevention of pulmonary hypertension. Am. J. Respir. Crit. Care Med. 179, 1048-1054 http://dx.doi.org/10.1164/rccm.200811-1678OC

Forhead A. J., Fowden A. L. (2014): Thyroid hormones in fetal growth and prepartum maturation. J. Endocrinol. 221, R87-103 http://dx.doi.org/10.1530/JOE-14-0025

Fouron J. C., Bourgin J. H., Letarte J., Dussault J. H., Ducharme G., Davignon A. (1982): Cardiac dimensions and myocardial function of infants with congenital hypothyroidism. An echocardiographic study. Br. Heart J. 47, 584-587 http://dx.doi.org/10.1136/hrt.47.6.584

Fowden A. L. (1995): Endocrine regulation of fetal growth. Reprod. Fertil. Dev. 7, 351-363 http://dx.doi.org/10.1071/RD9950351

Galton V. A., Martinez E., Hernandez A., Germain E. S., Bates J. M., Germain D. L. S. (1999): Pregnant rat uterus expresses high levels of the type 3 iodothyronine deiodinase. J. Clin. Invest. 103, 979-987 http://dx.doi.org/10.1172/JCI6073

Ghanbari M., Jeddi S., Bagheripuor F., Ghasemi A. (2015): The effect of maternal hypothyroidism on cardiac function and tolerance to ischemia-reperfusion injury in offspring male and female rats. J. Endocrinol. Invest. 38, 915-922 http://dx.doi.org/10.1007/s40618-015-0267-x

Ghasemi A., Mehrazin F., Zahediasl S. (2013): Effect of nitrate and Larginine therapy on nitric oxide levels in serum, heart, and aorta of fetal hypothyroid rats. J. Physiol. Biochem. 69, 751-759 http://dx.doi.org/10.1007/s13105-013-0251-x

Gomberg-Maitland M., Frishman W. H. (1998): Thyroid hormone and cardiovascular disease. Am. Heart J. 135, 187-196 http://dx.doi.org/10.1016/S0002-8703(98)70081-X

Guimaraes D. D., Carvalho C. C., Braga V.A. (2012): Scavenging of NADPH oxidase-derived superoxide anions improves depressed baroreflex sensitivity in spontaneously hypertensive rats. Clin. Exp. Pharmacol. Physiol. 39, 373-378 http://dx.doi.org/10.1111/j.1440-1681.2012.05679.x

Hu R. M., Wu L. M., Frank H. J., Pedram A., Levin E. R. (1994): Insulin stimulates thyroid hormone receptor alpha gene expression in cultured bovine aortic endothelial cells. Mol. Cell. Endocrinol. 103, 65-71 http://dx.doi.org/10.1016/0303-7207(94)90070-1

Idris I., Srinivasan R., Simm A., Page R. C. (2005): Maternal hypothyroidism in early and late gestation: effects on neonatal and obstetric outcome. Clin. Endocrinology 63, 560-565 http://dx.doi.org/10.1111/j.1365-2265.2005.02382.x

Karbalaei N., Ghasemi A., Faraji F., Zahediasl S. (2013): Comparison of the effect of maternal hypothyroidism on carbohydrate metabolism in young and aged male offspring in rats. Scand. J. Clin. Lab. Invest. 73, 87-94 http://dx.doi.org/10.3109/00365513.2012.743164

Langley-Evans S. C. (2006): Developmental programming of health and disease. Proc. Nutr. Soc. 65, 97-105 http://dx.doi.org/10.1079/PNS2005478

Laurberg P., Andersen S. L. (2014): Therapy of endocrine disease: antithyroid drug use in early pregnancy and birth defects: time windows of relative safety and high risk? Eur. J. Endocrinol. 171, R13-20 
http://dx.doi.org/10.1530/EJE-14-0135

Loss Ide O., Fernandes L. G., Martins C. D., Cardoso L. M., Silva M. E., Dias-Da-Silva V. J., Moraes M. F., Chianca D. A., Jr. (2007): Baroreflex dysfunction in rats submitted to protein restriction. Life Sci. 81, 944-950 http://dx.doi.org/10.1016/j.lfs.2007.08.005

Makino A., Suarez J., Wang H., Belke D. D., Scott B. T., Dillmann W. H. (2009): Thyroid hormone receptor-beta is associated with coronary angiogenesis during pathological cardiac hypertrophy. Endocrinology 150, 2008-2015 http://dx.doi.org/10.1210/en.2008-0634

Morvan E., Lima N. E., Machi J. F., Mostarda C., De Angelis K., Irigoyen M. C., Wichi R. B., Rodrigues B., Maifrino L. B. (2013): Metabolic, hemodynamic and structural adjustments to low intensity exercise training in a metabolic syndrome model. Cardiovasc. Diabetol. 12, 89 http://dx.doi.org/10.1186/1475-2840-12-89

Nambiar P. R., Palanisamy G. S., Okerberg C., Wolford A., Walters K., Buckbinder L., Reagan W. J. (2014): Toxicities associated with 1-month treatment with propylthiouracil (PTU) and methimazole (MMI) in male rats. Toxicol. Pathol. 42, 970-983 http://dx.doi.org/10.1177/0192623313502708

Nijsen M. J., De Ruiter G. J., Kasbergen C. M., De Wildt D. J. (2001): Effect of gamma-melanocyte-stimulating hormones on baroreflex sensitivity and cerebral blood flow autoregulation in rats. Cardiovasc. Res. 49, 226-233 http://dx.doi.org/10.1016/S0008-6363(00)00204-2

Noguchi A., Whitsett J. A. (1982): Ontogeny of alpha 1-adrenergic receptors in the rat myocardium: effects of hypothyroidism. Eur. J. Pharmacol. 86, 43-50 http://dx.doi.org/10.1016/0014-2999(82)90394-6

Olivetti G., Melissari M., Marchetti G., Anversa P. (1982): Quantitative structural changes of the rat thoracic aorta in early spontaneous hypertension. Tissue composition, and hypertrophy and hyperplasia of smooth muscle cells. Circ. Res. 51, 19-26 http://dx.doi.org/10.1161/01.RES.51.1.19

Reckelhoff J. F. (2001): Gender differences in the regulation of blood pressure. Hypertension 37, 1199-1208 http://dx.doi.org/10.1161/01.HYP.37.5.1199

Rhee S. S., Pearce E. N. (2011): The endocrine system and the heart: a review. Revista Espa-ola de Cardiología (English Edition) 64, 220-231 http://dx.doi.org/10.1016/j.rec.2010.10.016

Roland A. V., Nunemaker C. S., Keller S. R., Moenter S. M. (2010): Prenatal androgen exposure programs metabolic dysfunction in female mice. J. Endocrinol. 207, 213-223 http://dx.doi.org/10.1677/JOE-10-0217

Santos S. O., Loureiro S. M., Alves I. G., Jesus C. S., Santos P. R., Santos M. R., Dias D. P., Santana-Filho V. J., Badaue-Passos D., Jr. (2012): Experimental gestational hypothyroidism evokes hypertension in adult offspring rats. Auton. Neurosci. 170, 36-41 http://dx.doi.org/10.1016/j.autneu.2012.07.004

Sedaghat K., Zahediasl S., Ghasemi A. (2015): Gestational hypothyroidism-induced changes in L-type calcium channels of rat aorta smooth muscle and their impact on the responses to vasoconstrictors. Iran. J. Basic Med. Sci. 18, 172-179

Taylor P. N., Vaidya B. (2012): Side effects of anti-thyroid drugs and their impact on the choice of treatment for thyrotoxicosis in pregnancy. Eur. Thyroid. J. 1, 176-185 http://dx.doi.org/10.1159/000342920

Teng W., Shan Z., Patil-Sisodia K., Cooper D. S. (2013): Hypothyroidism in pregnancy. The Lancet Diabetes Endocrinol. 1, 228-237 http://dx.doi.org/10.1016/S2213-8587(13)70109-8

Tousson E., Ali E. M., Ibrahim W., Mansour M. A. (2012): Treatment with folic acid ameliorated the histopathological alterations caused by propylthiouracil-induced hypothyroid rat testes. Toxicol. Ind. Health 28, 566-576 http://dx.doi.org/10.1177/0748233711420469

Toyoda N., Yasuzawa-Amano S., Nomura E., Yamauchi A., Nishimura K., Ukita C., Morimoto S., Kosaki A., Iwasaka T., Harney J. W., Larsen P. R., Nishikawa M. (2009): Thyroid hormone activation in vascular smooth muscle cells is negatively regulated by glucocorticoid. Thyroid. 19, 755-763 http://dx.doi.org/10.1089/thy.2009.0044

Tzanetakou I. P., Mikhailidis D. P., Perrea D. N. (2011): Nutrition during pregnancy and the effect of carbohydrates on the offspring's metabolic profile: In search of the „perfect maternal diet“. Open Cardiovasc. Med. J. 5, 103-109 http://dx.doi.org/10.2174/1874192401105010103

Vane J. R., Anggard E. E., Botting R. M. (1990): Regulatory functions of the vascular endothelium. N. Engl. J. Med. 323, 27-36 http://dx.doi.org/10.1056/NEJM199007053230106

Williams F. L., Simpson J., Delahunty C., Ogston S. A., BongersSchokking J. J., Murphy N., Van Toor H., Wu S.-Y., Visser T. J., Hume R. (2004): Developmental trends in cord and postpartum serum thyroid hormones in preterm infants. J. Clin. Endocrinol. Metab. 89, 5314-5320 http://dx.doi.org/10.1210/jc.2004-0869

York T. P., Eaves L. J., Neale M. C., Strauss J. F. (2014): The contribution of genetic and environmental factors to the duration of pregnancy. Am. J. Obstet. Gynecol. 210, 398-405 http://dx.doi.org/10.1016/j.ajog.2013.10.001

Zaki S., Youssef M. (2013): Thyroid hormone dysfunctions affect the structure of rat thoracic aorta: a histological and morphometric study. Folia Morphol. 72, 333-339 http://dx.doi.org/10.5603/FM.2013.0056

Received: March 9, 2015

Final version accepted: April 29, 2016

First published online: August 16, 2016 